\title{
Commercial Shrimp Farming at Coastal Areas in Bangladesh and Its Effects on Livelihood and Environment: A Study on Paikgacha Upazila, Khulna
}

\author{
Md. Mohiuddin ${ }^{1 *}$, Samshad Nowreen ${ }^{2}$ and Uchinlayen ${ }^{2}$ \\ 1. Department of Geography and Environment, Jagannath University, Dhaka-1100, Bangladesh \\ 2. Department of Tourism and Hospitality Management, Dhaka University, Dhaka-1000, Bangladesh.
}

(Received: 18 May 2017; Accepted: 13 March 2018)

\begin{abstract}
The study focuses on the changing livelihood pattern and the environment through shrimp farming in Bangladesh where the country is one of the largest producers of shrimp in the whole world. Shrimp production sector is contributing to the national economy of Bangladesh very fast other than any other sectors. This sector is the second top production sector of the century. This study was based on survey method; especially survey was done by questionnaire survey, where the primary data were collected from questionnaire survey. Although the environmental impact of shrimp cultivation is very adverse, the sector is becoming more popular because of huge profit. Therefore, the study found the change in pattern along with occupation, land use practice, sources of food, specially protein intake, transportation etc. Furthermore, the study found the adverse impact of intruding brackish water on surrounding environment and both on flora and fauna.
\end{abstract}

Keywords: Livelihood, shrimp farming, coastal Bangladesh.

\section{Introduction}

Shrimp farming is surprisingly increasing in the world since 1970, the global demand of shrimp especially from USA, Europe and Japan the production expansion is hiking since seventies, and the production of shrimp increased from 9000 metric tons in 1970 to 1 million metric tons in $2000 .{ }^{1}$ The leading producing countries are Thailand, Indonesia, China, Bangladesh and Ecuador because of high demand and profitable business since 1980s. Firstly, growing economic activities are shrimp aquaculture in South-Asia and Pacific region where $85 \%$ shrimp farms are being practiced within the whole world. Bangladesh is among the fifth largest producers in the world. ${ }^{2}$ Based on climate, location, low farming cost, and national and international demand make the activities more attractive in Bangladesh especially coastal district including Khulna, Shatkhira, Bagherhat and Cox's bazaar. ${ }^{3}$ More than 244,000 hectares of land is used for shrimp farming in the southern portion of Bangladesh. ${ }^{4}$ Remarkable contribution to national income is seen every year from shrimp farming. ${ }^{5}$ Near about 600,000 people's livelihood depend on the sub-sectors of shrimp farming. ${ }^{6,7}$. The shrimp farming in southwestern side of Bangladesh supply huge stocks to the global market and it is the second highest foreign currency earner country in the world countries in this sector. ${ }^{8}$ Khulna region is very prominent for shrimp farming as it has turned the areas into a commercial shrimp production zone. For example Khulna region has earned around 0.02 million BDT per hector, where paddy could earn only 0.005 million BDT per hector in 2011. ${ }^{9}$ Shrimp farming is a profitable practice that can impact on livelihood, which need to be investigated. ${ }^{10}$ Coastal area is the dynamic and buffer zones connecting atmosphere, land and sea that provide the essential circumstance for coastal biodiversity and ecosystem which is susceptible to easily broken by human disturbance and physical instability. ${ }^{11}$ Environment remains badly affected through shrimp farming in various ways, ${ }^{12}$ like the water body is degrading and declining biodiversity. ${ }^{13}$ Discharging

*Author for correspondesnce. e-mail: mahigeo.jnu@gmail.com of heavy materials, nutrients, salt and natural matters are the reasons of rapid environmental pollution. ${ }^{14}$ Some groups of people are endangered for shrimp farming because there is absent of public policy and regulations. ${ }^{15}$ Few powerful people impose decision for their own interest but majority and rest of the coastal community deprived from natural resources they used before. ${ }^{16}$ Community participation is essential for adopting to shrimp farming policy and strategy for reducing the negative impact on society, economy and environment. ${ }^{17}$

\section{Objectives of the Study}

The main objective of this study is to identify the present status and changes of livelihood pattern for practicing of shrimp aquaculture of the coastal people. Other objective of this research is to find out overall environmental changes because of commercial shrimp farming.

\section{Methodology}

Survey method was followed to conduct this research. The survey had been done by questionnaire survey. The sample size for doing the survey was 100 among 1,25,200 (10 unions) of the study area that represent $0.08 \%$ population. The sample size had been determined by purposive random sampling technique. The 10 unions of the Paikgacha Upazila area (map 1), where the survey was conducted such as, Chnadkhali, Deluti, Garaikhali, Godipur, Haridhali, Kapilmuni, Laskhar, Lata, Raruli households and Soladana. The survey was conducted from November to December 2016. Secondary information was collected from the following sources: a) relevant documents of Bangladesh Bureau of Statistics (BBS), b) Published and unpublished reports and documents of relevant government nongovernment organizations, c) Survey of Bangladesh, d) Departments of Geography and Environment of Jagannath University and e) the Department of fisheries of Khulna and Paikgacha. Various national and international reports on shrimp farming issue in Bangladesh such as academic 
journal, books, newspapers, NGO publications and government records were considered.

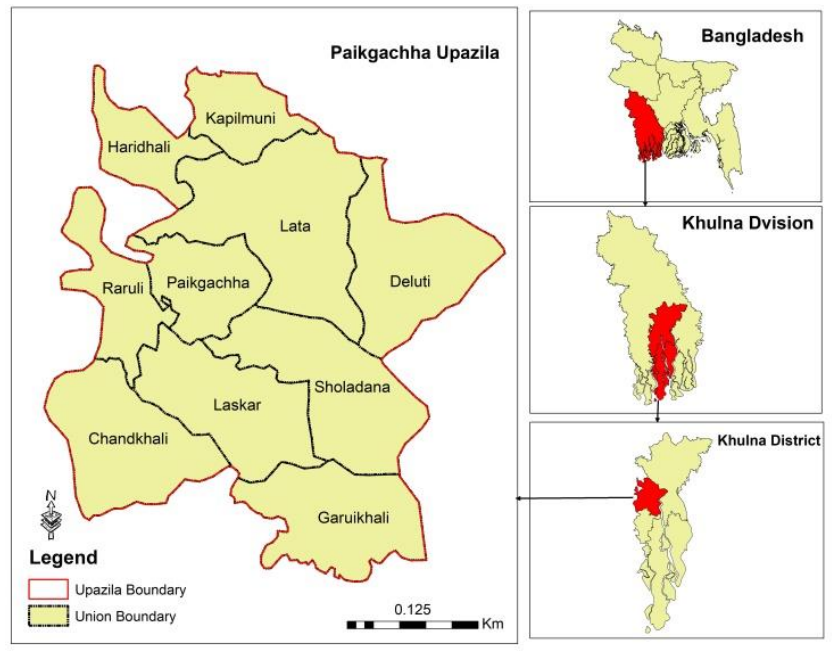

Map 1. Author's generated 2017.

\section{Result and Discussion}

\section{Changes of Livelihood and Lifestyle for Shrimp Farming}

\section{a) Change in occupations and income:}

Shrimp is the second highest earner importing product in Bangladesh $^{18}$ Easy and ready money making sector, and national and international huge demand enhancing shrimp farming in Bangladesh particularly in last couple of decades. The main occupation of the local people of the study area is crop cultivation; however, shrimp farming becomes the replacement of crop cultivation for generating more profit. Study shows that before 30 years $20 \%$ people of that area were involved in shrimp farming, $70 \%$ in crop farming. However, at present $58 \%$ people of the area are being involved with shrimp farming where $20 \%$ are involved in crop farming, and the rest of the people are involved with other tertiary economic activities those are related mostly with businesses especially shrimp related businesses. Some people also practice shrimp farming as their secondary occupation (Table 1). The annual income of $90 \%$ respondents was below 50,000BDT and $10 \%$ was above the $50,000 \mathrm{BDT}$ respectively prior to shrimp cultivation (30 years ago). At present, annual income of $28 \%$ people is below $1,00,000 \mathrm{bdt}$, income of $40 \%$ people is above $100,000 \mathrm{BDT}$, and $18 \%$ is above $1,50,000 \mathrm{BDT}$. So, annual income of all the people in the study area has increased because of shrimp farming (Field survey, 2016).

Table 1. Occupation before (30 years ago) and at present shrimp farming.

\begin{tabular}{|c|c|c|}
\hline Occupation & $\begin{array}{c}\text { Before (30 years } \\
\text { ago) }(\%)\end{array}$ & At present (\%) \\
\hline Farmer & 70 & 20 \\
\hline Day labor & 20 & 4 \\
\hline Employment & 6 & 9 \\
\hline
\end{tabular}

\begin{tabular}{|c|c|c|}
\hline Teacher & 4 & 6 \\
\hline Shrimp farmer & 0 & 58 \\
\hline Shrimp business & 0 & 3 \\
\hline Total & 100 & 100 \\
\hline
\end{tabular}

Source: Field Survey-2016

b) Change in food and drinking water sources:

Before 30 years, $89 \%$ people produced their crops in own land and $11 \%$ purchased from local market. The reason behind that is paddy was the dominant crop for their family support, and practice of agriculture was subsistence in nature. However, at present $64 \%$ people buy their staple food from market because shrimp farming is more profitable than crop cultivation, only $36 \%$ people cultivate crops seasonally especially at rainy season. Most of the respondent's livelihood pattern has been derived from agriculture. Prior to shrimp farming $76 \%$ people used to do livestock ranching for cultivation and milk production though now $15 \%$ people ranch livestock for milk production and business (Field survey, 2016).

Again, it has been found that $72 \%$ people used tube-well water and $27 \%$ people used pond water for drinking before shrimp farming, in contrast $84 \%$ people use tube-well water at the time of survey because of increasing salinity in the surface water for shrimp farming (Fig, 1).

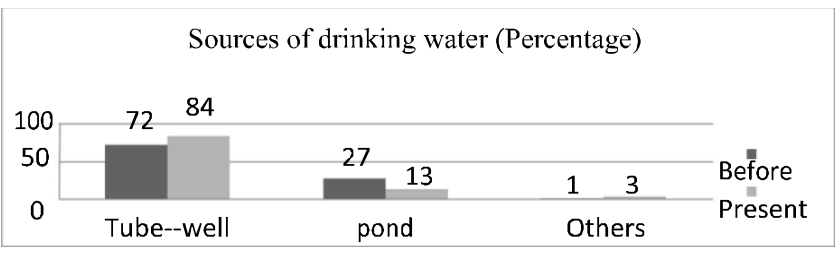

Fig. 1. Sources of drinking water before (30 years ago) and at present shrimp farming.

Source: Field Survey-2016

\section{c) Change in housing structure condition:}

Most of the people $(71 \%)$ of the study area were poor before the shrimp cultivation and their houses were also in poor condition. It has been found that $65 \%$ houses were mud-built and $22 \%$ houses were half brick-built. After practicing shrimp cultivation, mud-built houses are decreasing and brick-built houses are increasing (Fig 2).

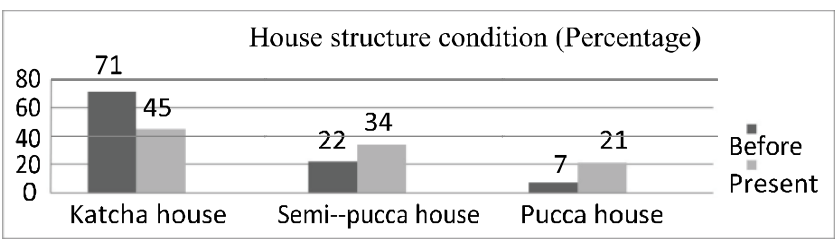

Fig. 2. House structure condition before (30 years ago) and at present shrimp Farming

Source: Field Survey-2016

\section{d) Change in land use pattern:}

A large number of lands (72\%) in this area had been used for agricultural activities only, $15 \%$ land for settlement 
where at present $65 \%$ land is used for shrimp farming for more profitable income. Moreover, waste land has been decreased gradually because of haat creation and seasonal vegetation for shrimp farm. Hence, some deep zones had been unusable for seasonal cropping which is now used for shrimp farming and to collect water in dry season. After 30 years in this area settlement and population also increased for shrimp farming as a potential and profitable income sectors (Table 2).

Table 2. Land use before and after shrimp cultivation

\begin{tabular}{|l|c|c|}
\hline \multicolumn{1}{|c|}{ Uses of land } & $\begin{array}{c}\text { Before (30 years ago) } \\
(\%)\end{array}$ & After (\%) \\
\hline Agricultural activities & 72 & 10 \\
\hline Residential & 15 & 18 \\
\hline Waste land & 6 & 1 \\
\hline Shrimp cultivation & 0 & 65 \\
\hline Others & 4 & 6 \\
\hline Total & 100 & 100 \\
\hline
\end{tabular}

Source: Field Survey-2016

Change in communication system: It has been found that $40 \%$ people communicate from one place to another by water-based vehicles (manual boat and engine-driven boat) for transporting their domestic goods, whereas $60 \%$ used road-ways before shrimp farming. However, at present maximum number of people $(91 \%)$ use road-ways because their economic condition has been developed along with their local transportation system for their self-solvency generated from shrimp farming (Field survey, 2016).

\section{Changed environment for shrimp farming}

Shrimp farming is increasing based on national and export demand especially last two decades, but surrounding environmental impact is unavoidable such as increasing salinity, loss of soil quality, loss of biodiversity (Islam et al, 2004). ${ }^{19}$

a) Land affected by salinity intrusion: In the study area total cultivable land is $30,523.67$ hectares, and fallow land is 485.22 hectares; 4 among them (79\% cultivable land) is used for crop cultivation and fallow land area is affected by the intrusion of salinity after shrimp aquaculture. Moreover, the land loses its fertility as well as productivity that hinder land from future use.

b) Impact on Trees: Because of shrimp farming salinity is increasing in the study area and for that many kind of trees are decreasing both in species verity and number. Most important species, which are becoming lost, are bamboo, jackfruit tree, mango tree, and other non-salinity tolerant trees. Only palm, coconut, date, rain tree and some other salinity tolerant vegetation could survive. Some people cut the trees for shrimp farming although it is another cause of soil erosion in the river banks that creates the scope of flooding in rainy season (Field survey, 2016).

c) Loss of Animals, Insects and Birds: Many verities of birds lost habitat along with their food supply because of decreased vegetation. The local fresh water fishes and organisms are the source of foods to the local and migratory birds, insects and organisms; however, after shrimp farming the water gradually becomes saline and intolerable for fresh water fishes. Thus, organisms lose their habitat and the dependent birds also lose their life and migrate to another place for continuing their food chain. Therefore, the environmental balance is breaking down, and degrading the adaptation capacity of local animals, insects and organism rapidly (Field survey, 2016).

\section{Conclusion}

Shrimp farming is not only economically beneficial for the rural communities but also it contributes to the development of the area especially south-western part of Bangladesh. Ironically, it has also negatively affected the livelihoods of landless and marginal farmers along with some environmental elements. People of the study area get the facilities of better services, goods and infrastructure, profitable business, better communication systems and other opportunities for the local people. People of the area improved their economic condition by not falling into the marginal level or below it with miserable life. It has been found that everyone has scope to contribute to the economy and the society. In some aspect trees, local animals, insects and birds lost their habitat for salinity through shrimp farming, which could be regarded as a threat to the local environment. However, local communities are not bothered about it as shrimp is known as white gold.

\section{References}

1. Alam, M.N.S., M. J. Phillips, 2004. Coastal Shrimp Cultivation System in Southwestern Bangladesh, Asia Fish Science, 17, 175-189.

2. Bangladesh Bureau of Statistics, 2008. Bangladesh Agriculture Census, Government People's republic of Bangladesh, Dhaka, Bangladesh.

3. Barraclough, S. and A. Finger-Stice, 1996. Some Ecological and Social Implication of Commercial Shrimp Farming in Asia,UNRISD, Discussion paper No.74, United Nation Research Organization for Social Development and Worldwide found for nature, Switzerland.

4. Belton, B., M. Karim, M. Thilsted, K.M. Jahan, W. Collisn , M. Phillips, 2011. Review of aquaculture and fish consumption in Bangladesh. Studies and reviews, The World fish centre, Penang, 76.

5. Deb, A.K., 1998 Fake blue revolution, Environmental and socio-economic impact of shrimp culture in coastal area Bangladesh, Ocean coast manage,41(1),63-88.

6. DOF., 2012. National Fish Week 2012 in Bengali Compendium, Department of Fisheries, Ministry of Fisheries and Livestock Bangladesh, 144.

7. Fatema, K., T.H. Miah, 2011. Rice versus shrimp farming in Khulna district of Bangladesh: interpretations of field-level data, Bangladesh Journal of Agriculture xxxiv, 1 \& 2, 129-140. Retrieved from https:// ageconsearch. umn.edu/record/199353/files/8. Kanij\% 20Fatema_\% 20 Research\% 20note-6.pdf 
8. Fernadez-Gimenez, M.E., Balard, H.L, Stuartevant, V.E., 2008. Adaptive management and Social learning in collaborative and community based monitoring: A study of five community based forestry organization in western USA, Ecol, Soc, 13(2), 4.

9. Food and Agriculture Organization-FAO., 2001. Fish STAT Plus, Universal software for fishery statistical time series2001.

10. Food and Agriculture Organization-FAO., 2002. FAO Year Book of Fishery Statistics, Aquaculture production, Food and Agriculture Organization of United Nations, Rome , Italy, 90, 2.

11. Huque, S., 2011. Efficiency and Institutional Issues of Shrimp Farming in Bangladesh, in Doppler.Bouer,S (Eds) Farming and Rural System Economics, Margraf Publishers (GmbH) Germany, 124, 164.

12. Islam S. M., Sarkar, M.J, Yamamoto,T., Wahab, M.A., Tanaka, M.2004 Water and sediment quality, partial mass budget and effluent $\mathrm{N}$ loading coastal brackish water farms in Bangladesh, Marine pollution bulletin. 48: 471-485

13. Kautsky, N., Ronnback, P., Tedengren, M., Troell, M. 2000 Ecosystem prospective on management of disease in shrimp farming, Aquaculture, 191, 145-61.
14. Ministry of Water Resources 2006 Coastal development strategies and water resources planning organization, Dhaka, Bangladesh. Retrieved from http://www.mowr.gov.bd/ Documents/COASTAL\%2520DEVELOPMENT\%2520STR ATEGY\%2520\%2528English\%2529.pdf

15. Robinson, T.P., G. Franceschini, and W. Wint, 2007. The Food and Agriculture Organization's gridded livestock of the world. Vet Italy, 43(3), 745-751.

16. Senarath U et al 2001 environmental issue in brackish water shrimp aquaculture in Sri Lanka, environmental Management, 27(3), 335-48.

17. Sun, Y., Jian, L., Ye, C., Feng, L.1997 Dissolving of N and P from newborn remain produced feeding and changing pattern in shrimp pond, Chinese journal of ecology, 8(5), 541-44.

18. USAID. 2006 A Pro-poor Analysis of the Shrimp Sector in Bangladesh, Great Access to Trade (GATE), project Development and Training Services (DTS), Dhaka, Bangladesh, 93.

19. Viles, H., Spencer, T., 1995. Coastal problems: geomorphology, ecology and society at the coast. Edward Arnold, Great Britain, pp. 350. 